ex Instituto Archaeologico Universitatis de Rolando Eötvös nominatae

C

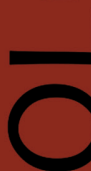

ப

$\varangle$

工

$\cup$

ه

$<$

in

ㄴ
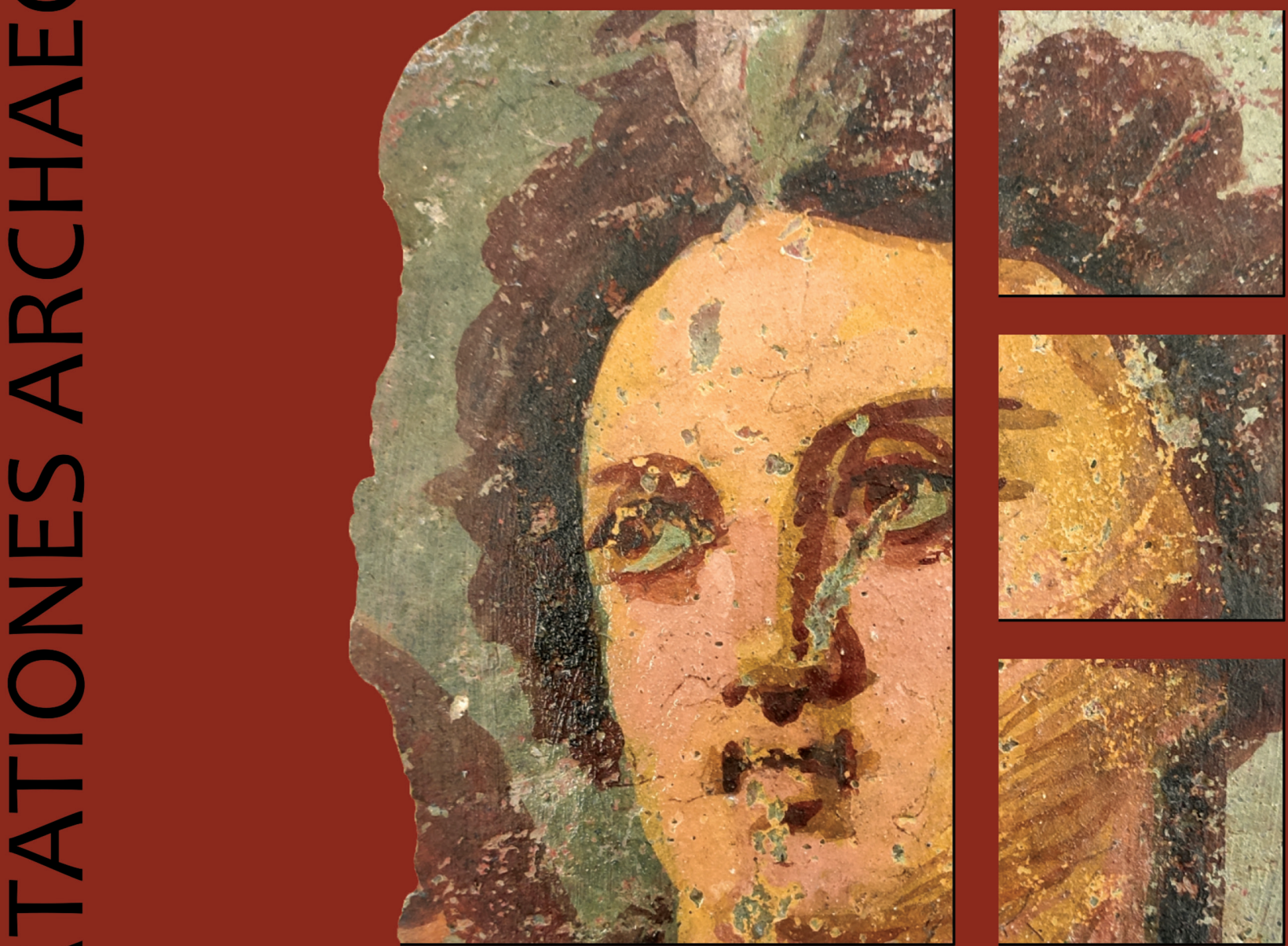

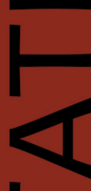

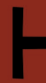

ח

Ш

un

n

0
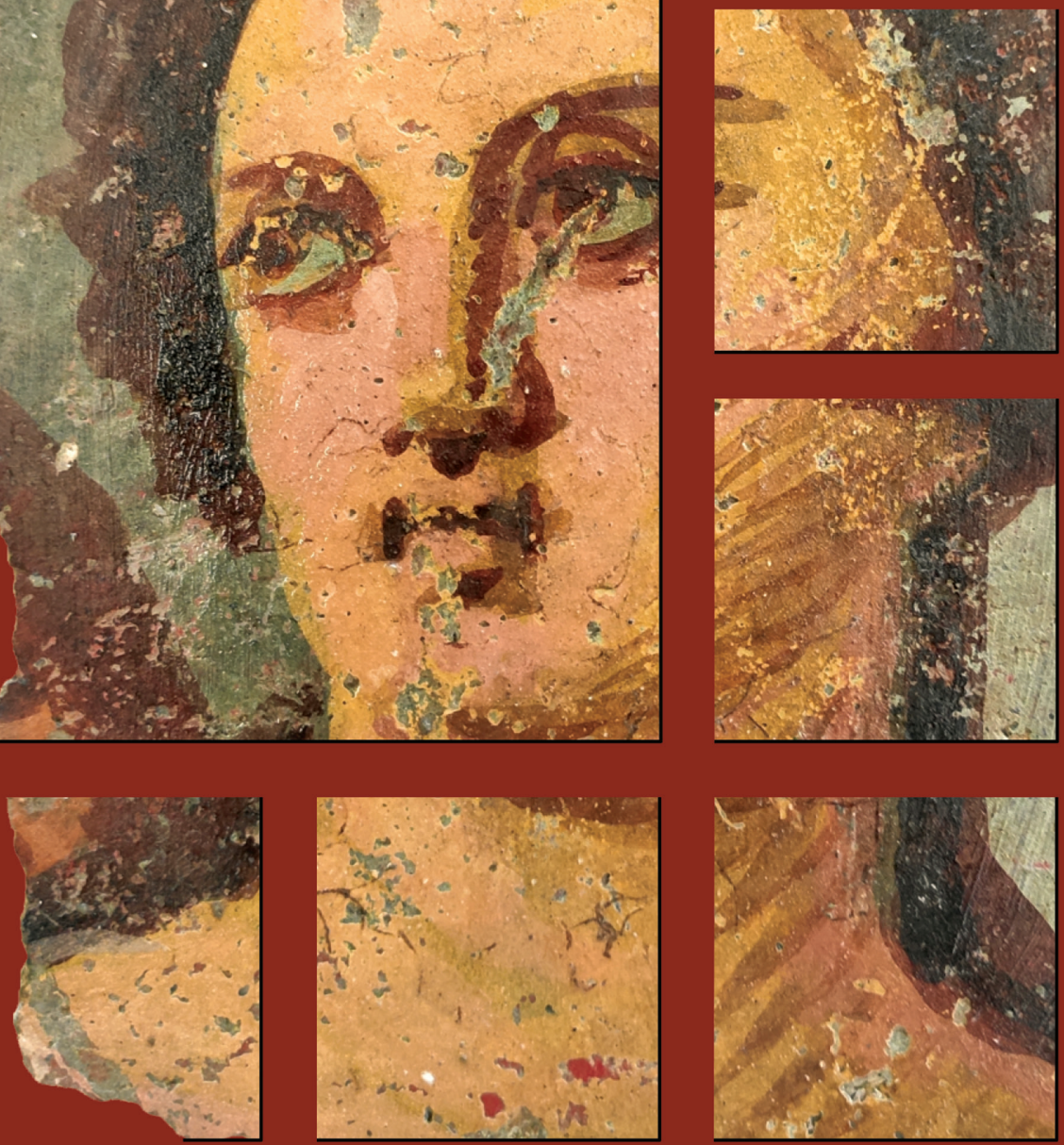

Serp 30 No. 8. 2020 


\section{Dissertationes Archaeologicae ex Instituto Archaeologico}

Universitatis de Rolando Eötvös nominatae Ser. 3. No. 8.

Budapest 2020 
Dissertationes Archaeologicae ex Instituto Archaeologico Universitatis de Rolando Eötvös nominatae Ser. 3. No. 8.

Editor-in-chief:

DÁvid Bartus

Editorial board:

LÁsZló BARTOSIEWICZ

LÁsZLÓ BORHY

ZOLTÁN CZAJLIK

IsTVÁN FELD

GÁBOR KALLA

PÁL RACZKY

MiKLÓS SZABÓ

Tivadar Vida

Technical editor:

Gábor VÁczi

Proofreading:

Szilvia BARTUS-SzÖLLŐsI

Zsófia KondÉ

Márton SZILÁGYI

Aviable online at http://ojs.elte.hu/dissarch

Contact: dissarch@btk.elte.hu

ISSN 2064-4574

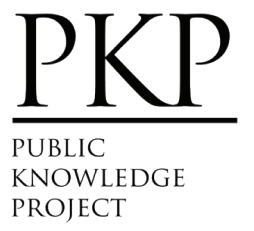

๑ ELTE Eötvös Loránd University, Institute of Archaeological Sciences

Layout and cover design: Gábor Váczi

Budapest 2020 


\section{CONTENTS}

\section{ARTICLES}

Maciej WAWRZCZAK - Zuzana KASENČÁKovÁ

Stará L'ubovña - Lesopark. Late Palaeolithic site and the problems associated with raw material mining

Attila PÉNTEK - Norbert FARAgó

Chipped stone assemblages from Schleswig-Holstein (North Germany) in the collection of the Institute of Archaeological Sciences - ELTE Eötvös Loránd University

Bence Soós 49

Middle Iron Age Cemetery from Alsónyék, Hungary

Tamás Szeniczey - Tamás Hajdu 107

Appendix - Results of the analysis of the Early Iron Age human remains unearthed at Alsónyék, Hungary

Lajos JuHÁsz - József Géza Kiss

Bound in bronze - a Roman bronze statuette of a barbarian prisoner

Csilla SÁRó

The fibula production of Brigetio: clay moulds

\section{Field Reports}

András Füzesi - Knut Rassmann - Eszter BÁnffy - Hajo Hoehler-Brockmann -

Gábor Kalla - Nóra Szabó - Márton SzIlágyi - Pál Raczky

Test excavation of the "pseudo-ditch" system of the Late Neolithic settlement complex at Öcsöd-Kováshalom on the Great Hungarian Plain

Gábor VÁczi - László RupNIK - Zoltán CZAJLIK - Gábor MEsterházy Bettina BitTner - Kristóf FÜlöP - Denisa M. LÖNHARdT - Nóra Szabó

The results of a non-destructive site exploration and a rescue excavation at the site of Pusztaszabolcs-Dohányos völgy északi part

Dávid BArtus - László Borhy - Szilvia JohÁczi - Emese SzÁmadó 181

Excavations in the legionary fortress of Brigetio in 2019 
Dávid BArtus - László Borhy - Emese SzÁmadó - Lajos Juhász - Bence Simon -

Ferenc Barna - Anita Benes - Szilvia Joháczi - Rita Olasz - Melinda Szabó

Excavations in Brigetio in 2020

\section{Thesis Abstracts}

Anett OszTÁs

The settlement history of Alsónyék-Bátaszék.

Complex analysis of its buildings in the context of the Lengyel culture

Csilla SzÁRAz

The region of the Zala and Mura Rivers (Zala County) in the Late Bronze Age.

Late Tumulus and Urnfield period

Ágnes KIRÁly

Human remains unearthed in settlement context from the Late Bronze Age -

Early Iron Age (Reinecke BD-HaB3) Northeastern Hungary

Gergely BóKA

Transformation of settlement history in the Körös Region in the period between the Late Bronze Age and the end of Iron Age

Gabriella G. DeLbó

Pottery production of the settlement complex of Brigetio

Adrienn Katalin BLAY

Die Beziehungen zwischen dem Karpatenbecken und dem Mediterraneum

von der II. Hälfte des 6. bis zum 8. Jahrhundert n. Chr. anhand Schmuckstücken

und Kleidungszubehör

Levente SAMU

293

Die mediterranen Kontakte des Karpatenbeckens in der Früh- und Mittel-

awarenzeit im Licht der Männerkleidung. Gürtelschnallen und Gürtelgarnituren

\section{REviEWS}

Gábor MESTERHÁZY

Czajlik, Z. - Črešnar, M. - Doneus, M. - Fera, M. - Hellmith Kramberger, A. Mele, M. (eds): Researching Archaelogical Landscapes Across Borders - Strategies,

Methods and Decisions for the 21th Century. Graz-Budapest, 2019. 


\title{
Stará L'ubovňa - Lesopark. Late Palaeolithic site and the problems associated with raw material mining
}

\author{
Maciej WAWRZCZAK \\ Institute of Archaeology and Ethnology \\ Polish Academy of Sciences \\ Institute of Archaeology \\ Slovakian Academy of Sciences \\ Subdivision - OZV Spǐ̌ \\ m.wawrzczak@interia.pl
}

Zuzana KASENČÁKovÁ
376 A.D. Ltd.
Prešov

kasencakova.zuzana@gmail.com

\begin{abstract}
A new archaeological site was discovered accidentally in year 2018. A surface survey revealed stone artefacts, which were generally dated to the Late Palaeolithic. Later, archaeological sondages were opened and newly found stone artifacts proved earliest dating. Furthermore, it was confirmed that local radiolarites were exploited by Late Palaeolithic societies.
\end{abstract}

\section{Introduction}

Research in the mountainous areas are undoubtedly one of the most important directions within the archaeological field of study. They indicate that geographically diverse communities were settled since the Palaeolithic. Nowadays, hardly accessible mountainous areas are very interesting places for archaeological works, mostly due to existing dense vegetation.

Before 2018, archaeological works in this area had been only concentrated in the valley of Poprad, where a Palaeolithic site was localized with material dated mainly to the Late Palaeolithic (Epigravettian and Magdalenian cultures). Moreover, Middle Palaeolithic artefacts and Neolithic materials were found there also. ${ }^{1}$ However, this site is located in a different landscape zone, than the newly discovered place, described below.

The Stará Lubovňa - Lesopark site was localized surprisingly during a family trip to a recreational area of the town, where stone materials were found on the surface. After the site was thoroughly surveyed and some material was collected, it was decided to begin archaeological excavations. The purpose of this research was to describe its chronological position. During this works more artefacts were discovered, which are kept together with the documentation in the Museum of Stará Lubovňa. ${ }^{2}$

\section{Site location}

The newly discovered site is located in the northern part of Slovakia (Fig. 1.1), within a recreational zone in the area of Stará L'ubovňa. It is located in L'ubovnianska vrchovina, which is a

1 VALDE-NowAK et al. 2007.

2 KASENČÁKOVÁ - WAWrZCZAK 2018; KuČERovÁ et al. 2020, 86. 
part of the Magura nappe-group of the flysch belt of the Magura unit, ${ }^{3}$ made of brown, clayey soil. ${ }^{4}$ At this moment the site is covered by meadows, overgrown with grass and nearby forest (Fig. 1.2). It's situated on the southern slope of the hill and also spreads to the relatively flat area of the foothill. The hill extends to a small, unnamed watercourse, which is a left-bank tributary of the Pasterník Stream - a right-bank tributary of Poprad River (Fig. 1.3). The research area is situated at an altitude of $676 \mathrm{~m}$ a.s.l.

1

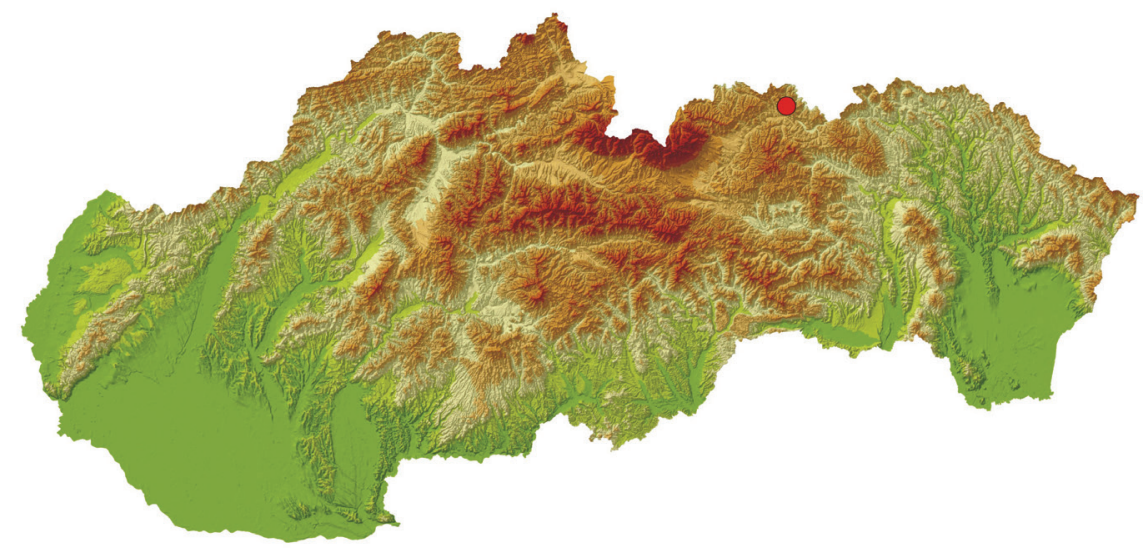

2
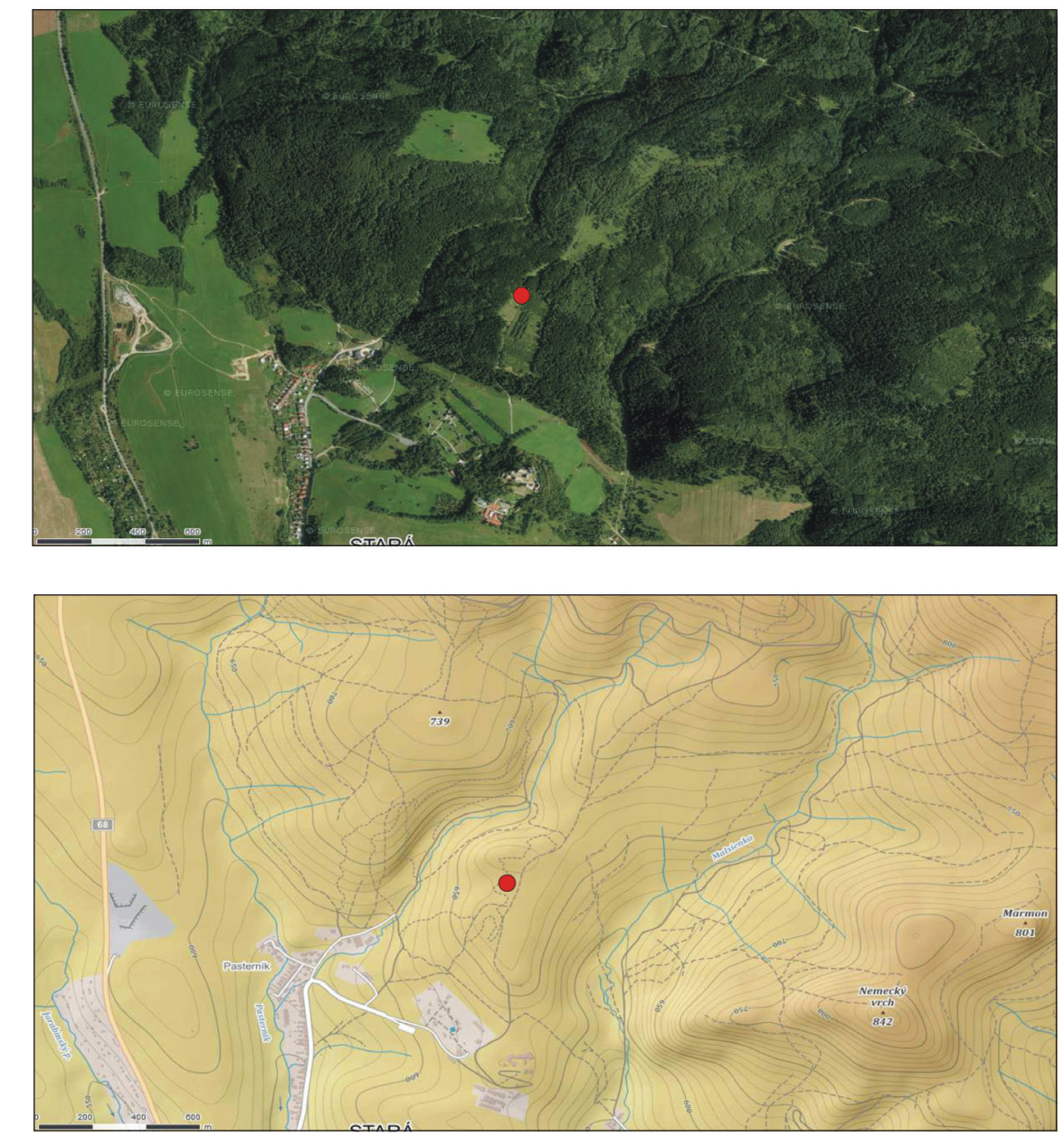

Fig. 1. The location of Stará Lubovňa - Lesopark site: 1 - in the area of Slovakia, 2 - site location in terms of vegetation cover, 3 - in the relation to landforms.

3 NЕмС̌ок 1990, 52.

4 KunÁková et al. 2016, 340. 


\section{Archaeological excavations}

As it was mentioned above, the site was accidentally discovered. A flake made of red-green radiolarite was found at the surface in the border zone between the meadow and the forest (Fig. 2.1), while a core made of green radiolarite (Fig. 2.2), a blade (Fig. 2.3) and five flakes made of red radiolarite (Fig. 2.4-8) were found in the forest. Despite the fact, that blade and flakes are not very characteristic and primarily came from the first stages of the raw material processing, the found core seemed to be dated to the Late Palaeolithic period. ${ }^{5}$

The discovery of the artefacts led to a decision to conduct a small archaeological excavation and two small sondages were established. Sondage $1 / 2018$ (size $2 \times 1 \mathrm{~m}$ ) was located on the border of meadow and the forest, whereas $2 / 2018$ sondage was situated in the forest (Fig. 3). Works were carried out manually and exploration of levels was done every $5 \mathrm{~cm}$.

\section{Stratigraphy}

The stratigraphy revealed during the archaeological works can be summarized as follows (Fig. 4: A.1 - W profile, A.2 - N profile, B. 1 - N profile, B. 2 - W profile): there was a $30-40 \mathrm{~cm}$ thick clay layer (2) of brown colour under a few centimetres thick, dark brown humus layer (1); the clay layer was situated directly on barren soil in the form of grey, impermeable layer of loam (3). Furthermore in the 1/2018 sondage, the presence of orange sandy layer (4) with lower (clayey) layer admixture (Fig. 4.A.2) was confirmed. In both cases the cultural layer was contemporaneous with layer 2, except that in $2 / 2018$ sondage artefacts were also found in the humus layer (layer 1).

In both sondages stone artifacts were not associated in clusters, but relatively evenly dispersed (Fig. 5.A,B). Also, no clusters were observed in the next exploration levels. The most number of artefacts in cultural layer were between $25-40 \mathrm{~cm}$ in sondage $1 / 2018$ and $10-20 \mathrm{~cm}$ in sondage $2 / 2018$.

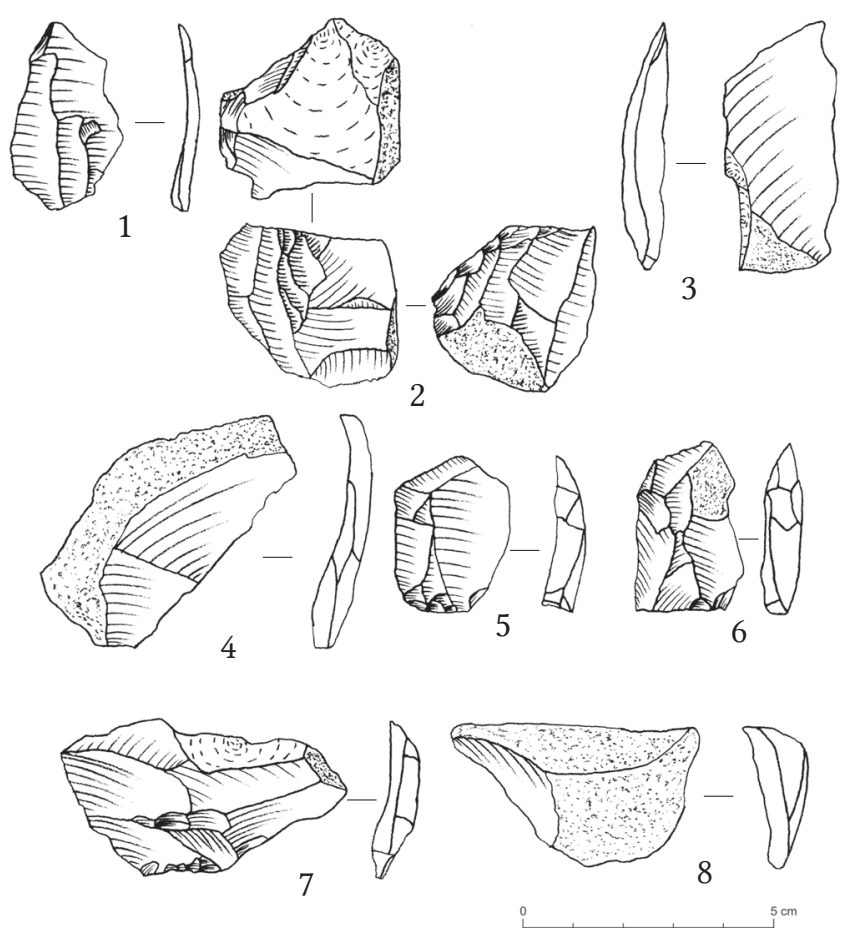

Fig. 2. Stará Lubovňa - Lesopark site. Stone artifacts found during surface survey: 1, 4-8 - flakes, 2 - core, 3 - blade. Raw materials: 1 - red-green radiolarite, 2 - green radio-larite, 3-8 - red radiolarite.

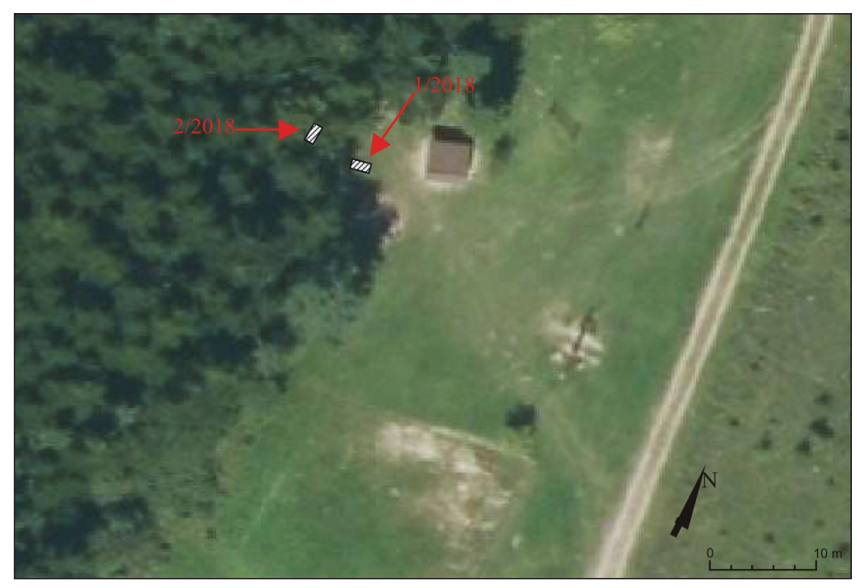

Fig. 3. The location of sondages (test excavations) in Stará L'ubovňa - Lesopark site.

5 comp. BAŃDo et al. 1992, 23. Fig. 12.2. 

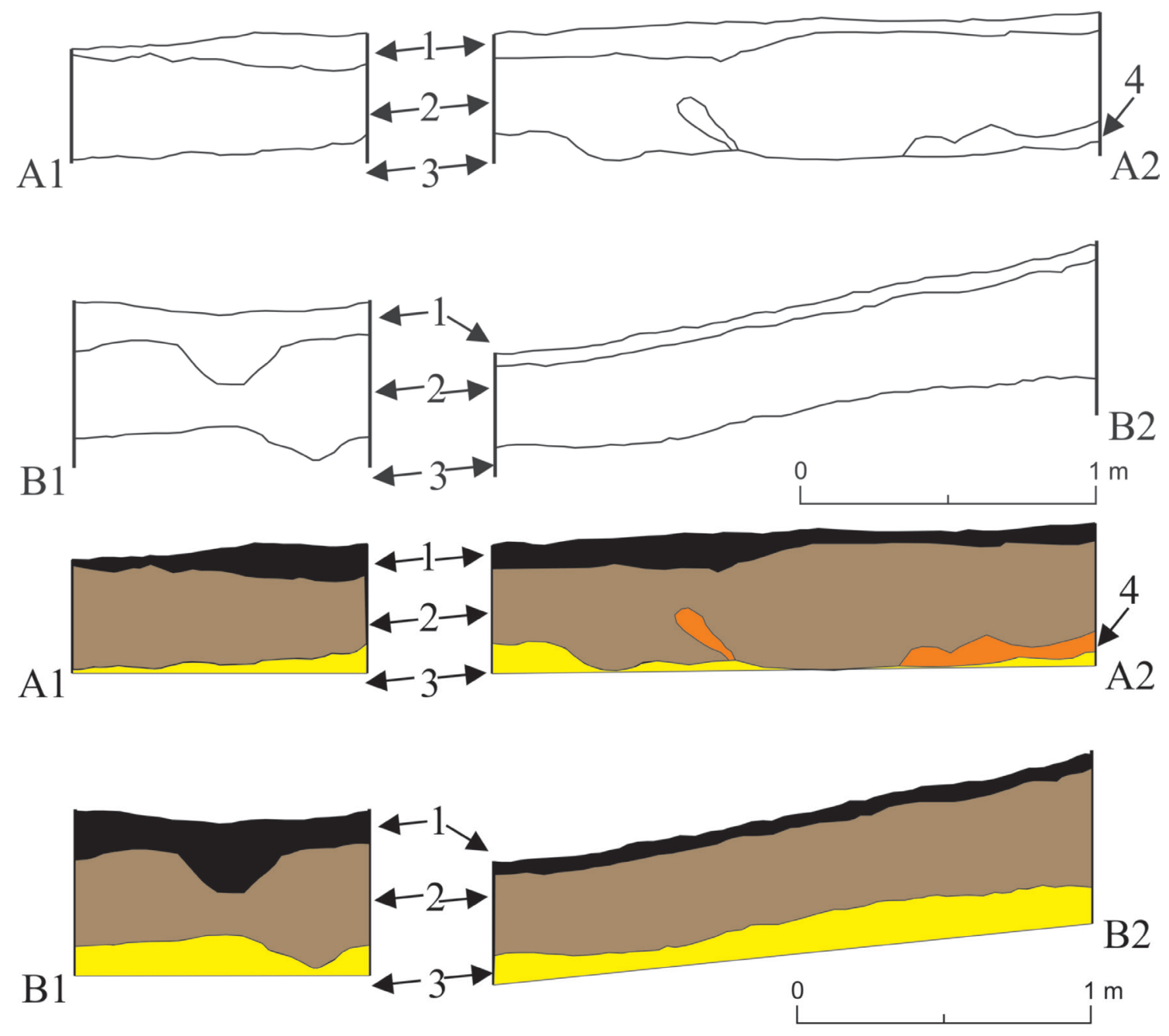

Fig. 4. Stratigraphy of 1/2018 (A) and 2/2018 (B) sondages located in Stará L'ubovňa - Lesopark site. 1 - dark brown hummus, 2 - brown loamy clay (cultural layer), 3 - grey loamy barren soil, 4 - orange sandy-loamy layer.

\section{Stone items}

During archaeological works 196 various stone materials were discovered in both sondages: 105 pieces in 1/2018 sondage and 91 pieces within 2/2018 sondage. Some of the items were just natural chunks that didn't show any marks of intentional knapping. This category included 9 objects in 1/2018 sondage and 39 pieces in 2/2018 sondage (Fig. 6). It may indicate differences in intra-site organization.

Stone materials that originated from both sondages can be assigned in $100 \%$ as made from local radiolarite. In the nearest area, there are radiolarite outcrops, in example in Jarabina or Litmanová villages, ${ }^{6}$ so this raw material have local origin. The most frequent is the red colour variant, represented by 82 items in the $1 / 2018$ sondage and 88 items in $2 / 2018$ sondage. The percentage of radiolarite varieties confirms that certain varieties were much more prefered than the other (Fig. 7). It is worth to mention that varieties of red radiolarite were mainly used also in the site of Stará L'ubovňa - Pod Štokom II. ${ }^{7}$

6 see BIERNAT et al. 2013, 2 for further reading.

7 see VAldE-NowaK et al. 2007, 11. Tab. 2. 


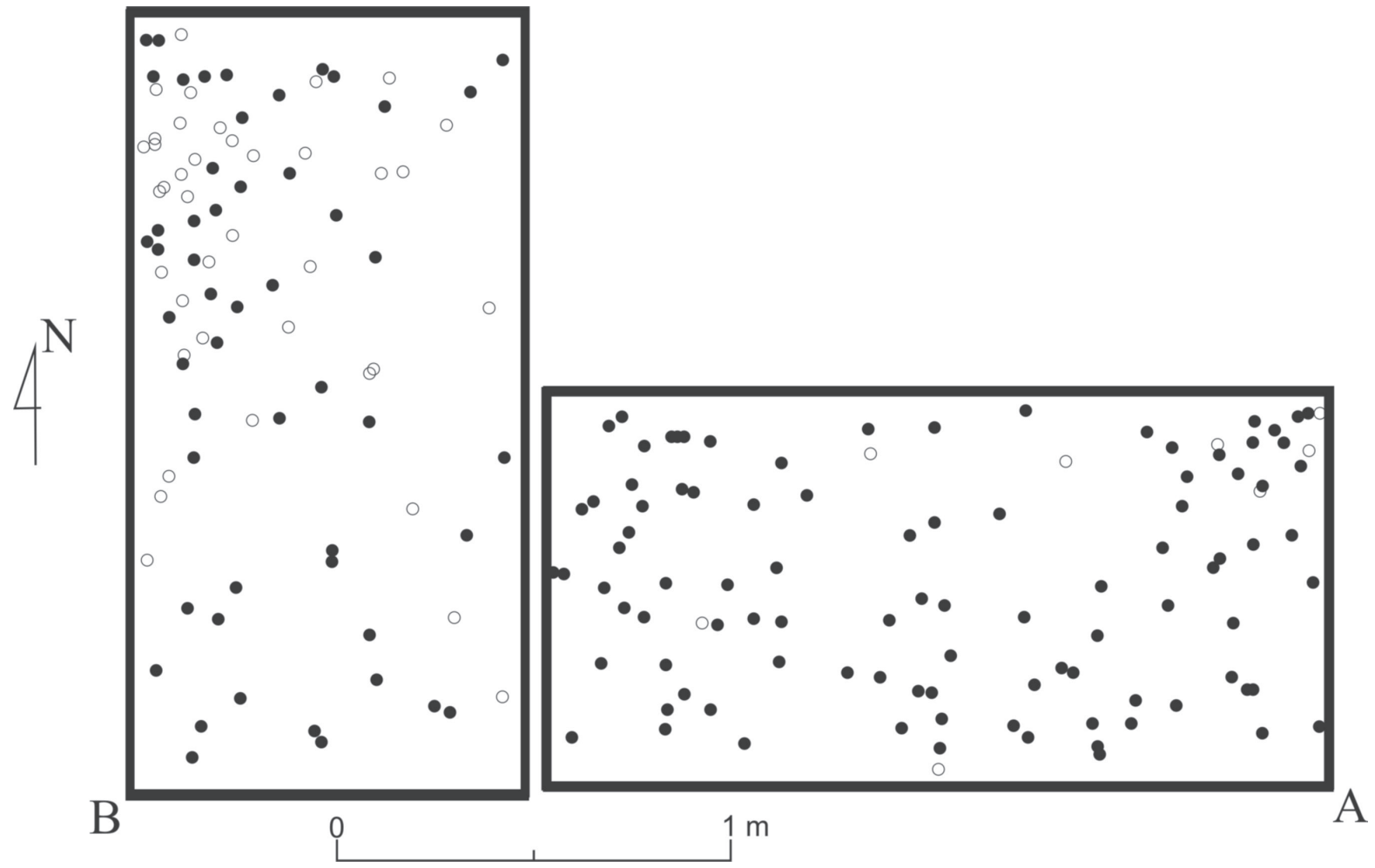

Fig. 5. Planigraphy of stone materials in Stará Lubovňa - Lesopark site: 1/2018 (A) sondage and 2/2018 (B) sondage. Full rectangle - artifact - empty rectangle - natural raw material.
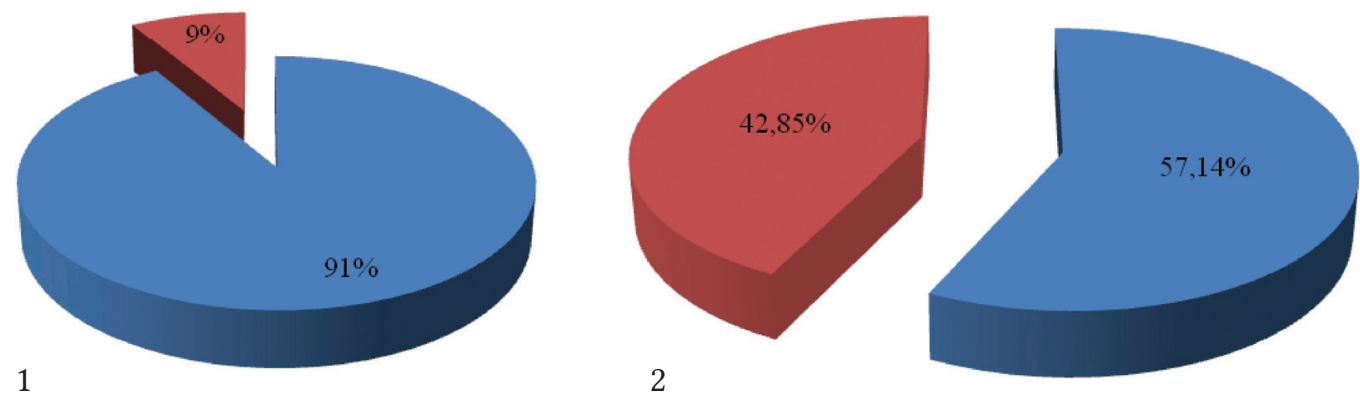

martifacts

- raw material

Fig. 6. Differences in stone materials - comparison of artifacts and raw material collected in Stará Lubovňa - Lesopark site: $1-1 / 2018$ sondage, $2-2 / 2018$ sondage.
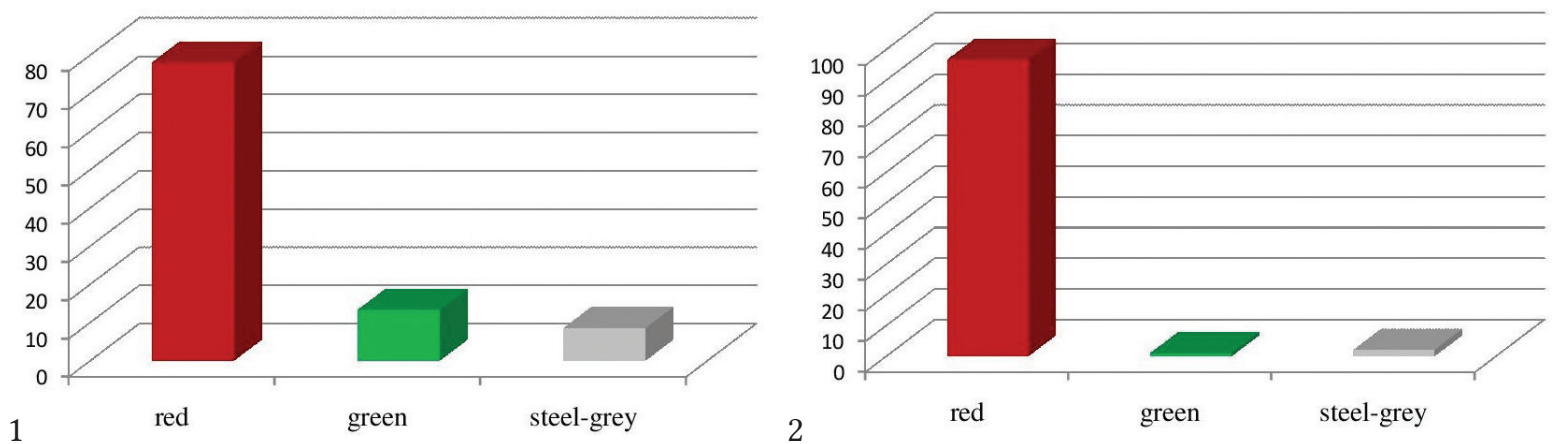

Fig. 7. Diversity of stone materials showing radiolarite colour variations in Stará Lubovňa - Lesopark site: $1-1 / 2018$ sondage, $2-2 / 2018$ sondage. 


\section{Stone artefacts}

During the archaeological excavations further divergence were confirmed between the both sondages. Apart from differences in participation of natural chunks which didn't have any marks of knapping in 1/2018 and 2/2018 (see above), it was noticed that there were also some dissimilarities between both sondages in the structure of the collection. The data is displayed on Figure 8 and Table 1.

The calculation shows, that the largest percentage in $1 / 2018$ sondage is represented by negative chunks, followed by flakes and tools (Fig. 8.1). The most numerous in $2 / 2018$ sondage are flakes, followed by negative chunks, while tools are the third numerous (Fig. 8.2).
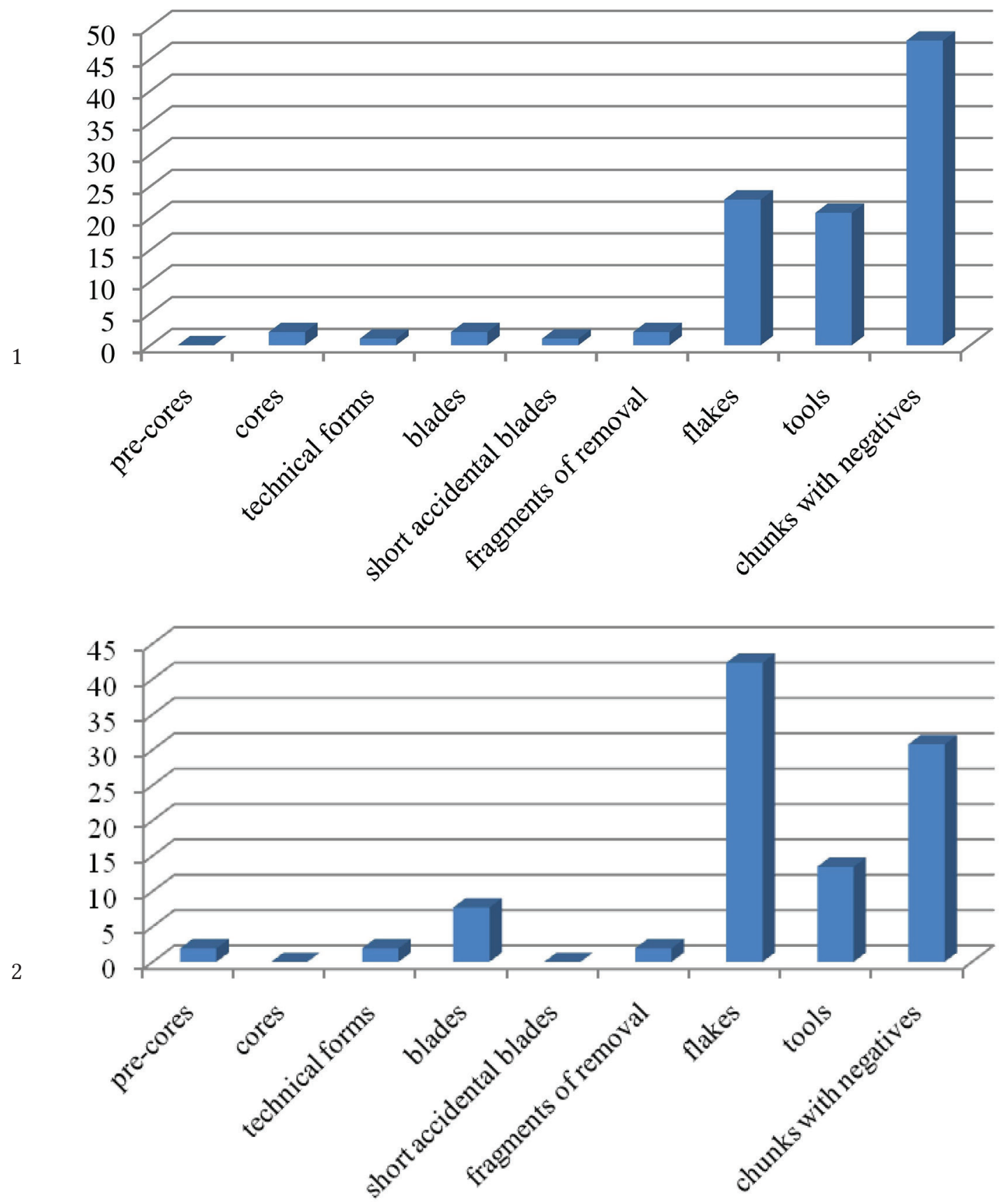

Fig. 8. The types of artifacts collected in Stará Lubovňa - Lesopark site: 1 - 1/2018 sondage, 2 - 2/2018 sondage. 

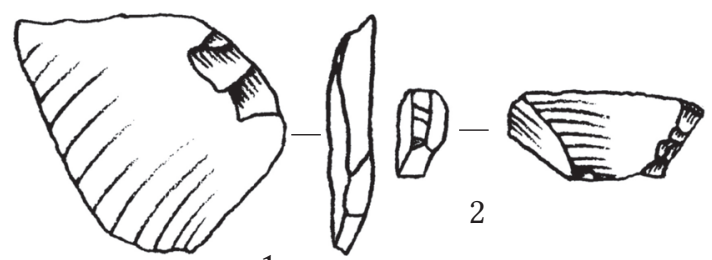

1
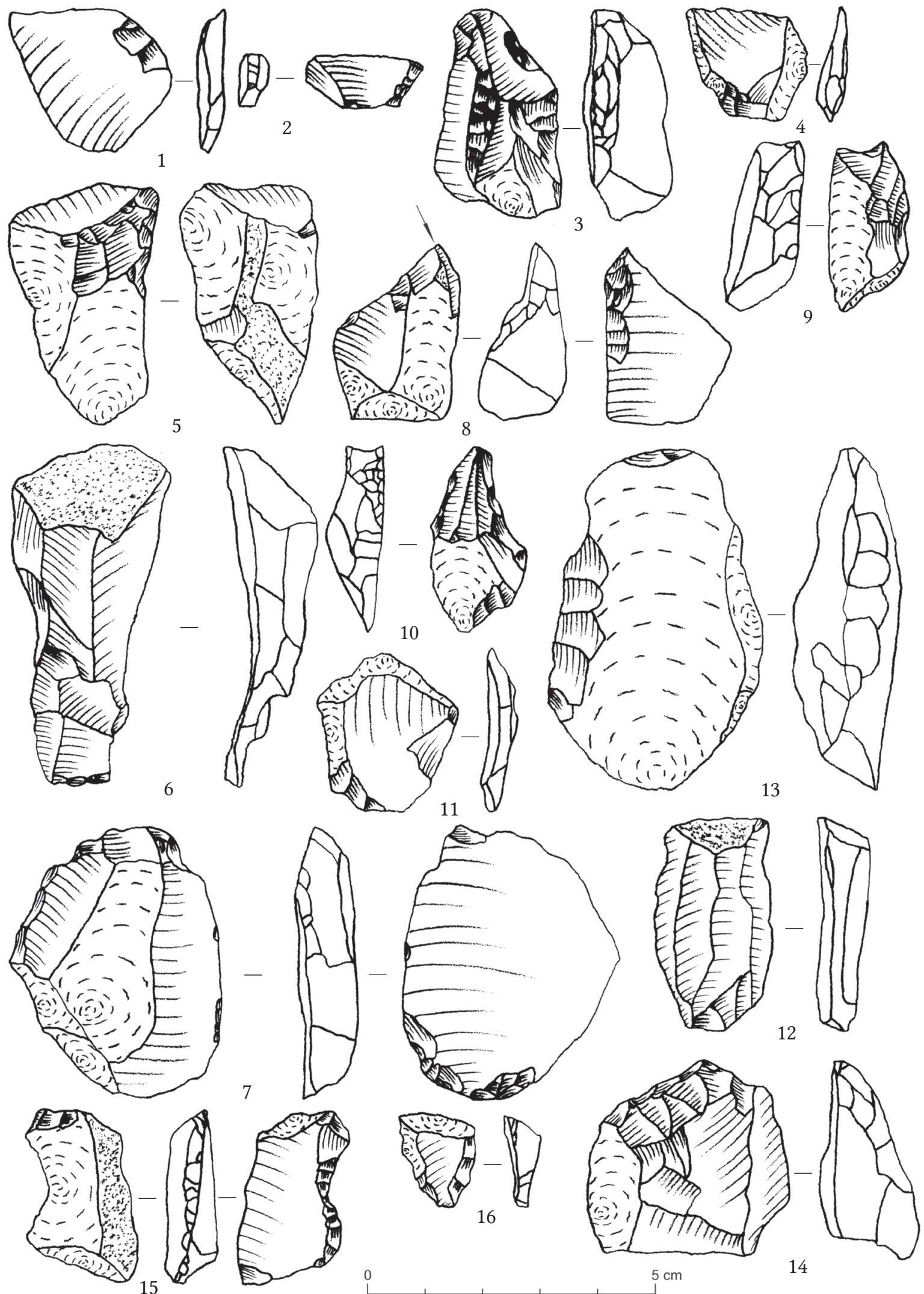

Fig. 9. Stone artifacts from 1/2018 sondage in Stará Lubovňa - Lesopark site: 1, 4, 11 - flakes, 2, 16 fragments of retouched blades or flakes, 3, 9, 10 - perforators, 5 - initial core, 6 - crested blade of the second series, 7 - combined tool end-scraper + knife, 8 - medial truncation burin, 12 - accidental blade, 13 - knife (?), 14 - end-scraper, 15 - fragment of retouched flake. Raw materials: 1-11, 15, 16 - red radiolarite, 12 - steel-grey radiolarite, 13, 14 - green radiolarite. 
Therefore, the explanation about functional differentiation of these places seems acceptable. Both sondages revealed large percentage of negative chunks. High rate of this kind of artefacts probably resulted from core exploitations or these products are fragments of cores. ${ }^{8}$ It is a common feature of both places.

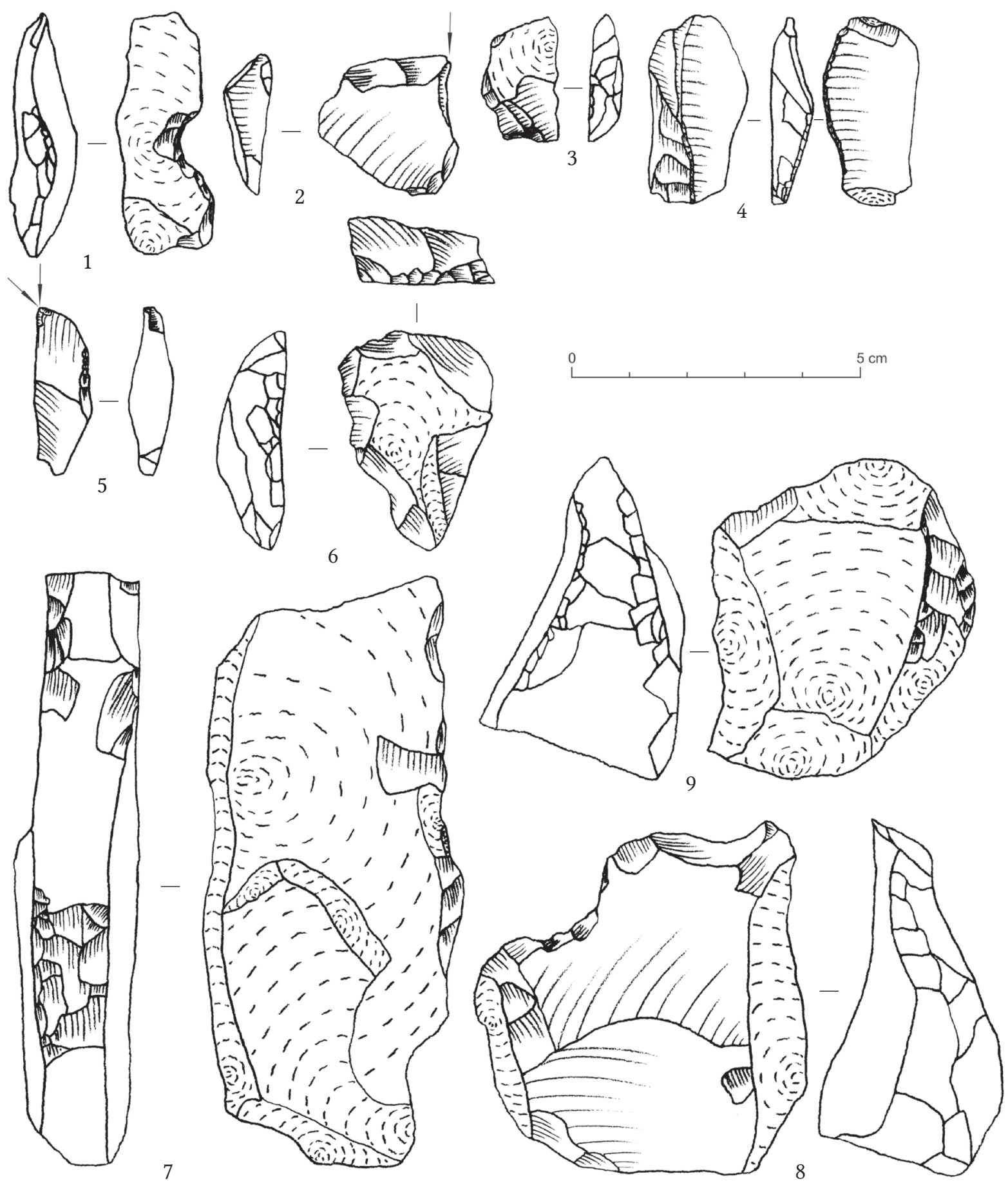

Fig. 10. Stone artifacts from 1/2018 sondage in Stará Lubovňa - Lesopark site: 1 - retouched natural stone, 2 - truncated burin, 3 - fragment of retouched flake, 4 - fragment of retouched crested blade of the second series, 5 - dihedral burin, 6 - amorphous end-scraper, 7, 8 - mining tools, 9 - a tool in the initial stage of development. Raw materials: 1-6, 8, 9 - red radiolarite, 7 - green radiolarite. 


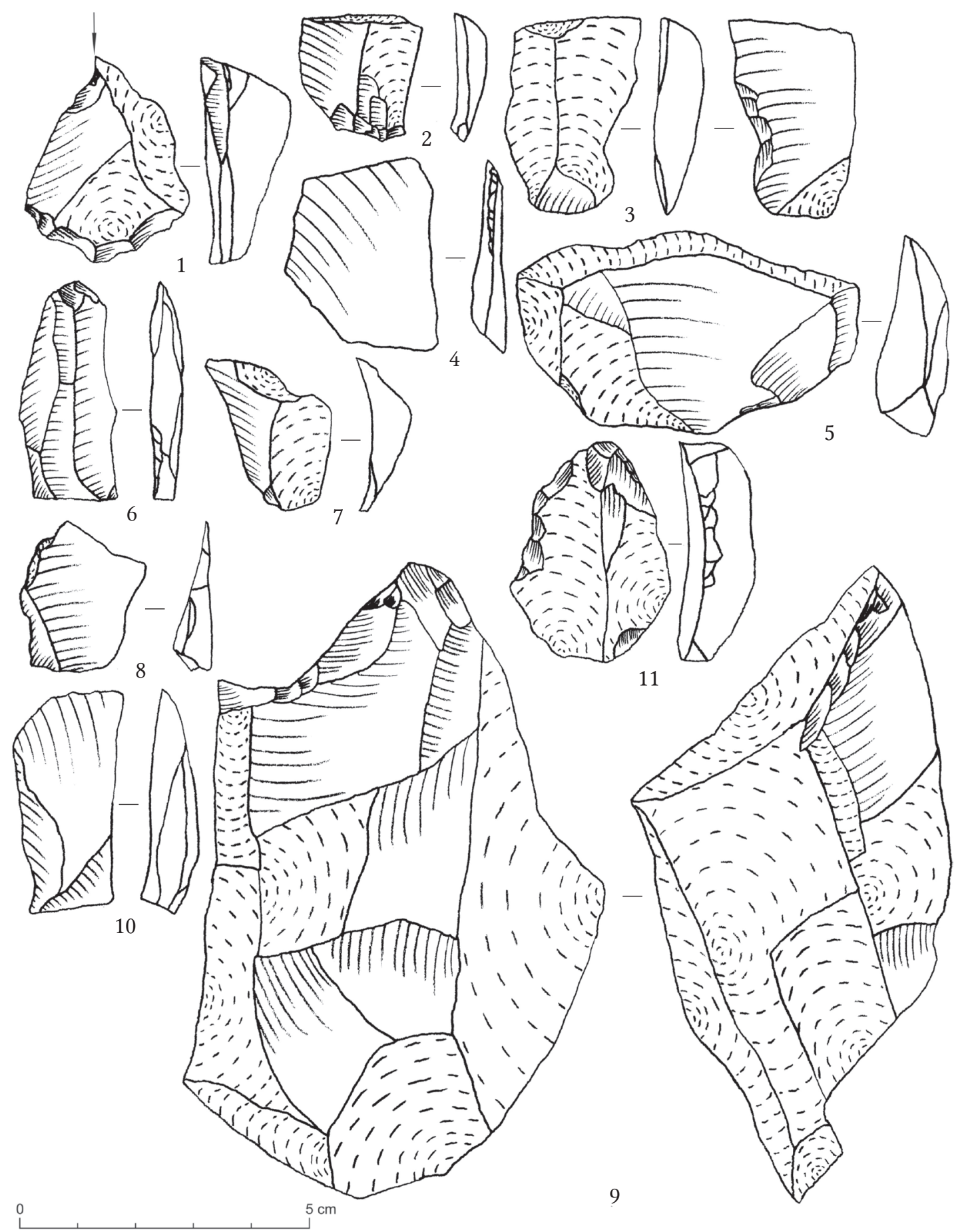

Fig. 11. Stone artifacts from 2/2018 sondage in Stará L’ubovňa - Lesopark site: 1 - single blow burin, 2 - fragment of blade or flake, 3 - fragment of retouched blade, 4, 11 - retouched flakes, 5, 7, 8 - flakes, 6 - fragment of blade from bipolar core, 9 - pre-core, 10 - blade. Raw materials: all made of red radiolarite.

As mentioned earlier, certain divergence appeared at the same time. Statistically, more tools are in $1 / 2018$ sondage, whereas flakes predominate in $2 / 2018$. It may prove the preliminary treatment of raw stone materials that occurred in places covered nowadays with forest, and further act of preparing products (cores, semi-products, tools) in places nowadays dominated by meadows. It is more likely, when we take a look at flakes category from 2/2018 sondage. These are massive cortex forms (cortical flakes), with big bulbs visible (Fig. 12.2-7,9). They 


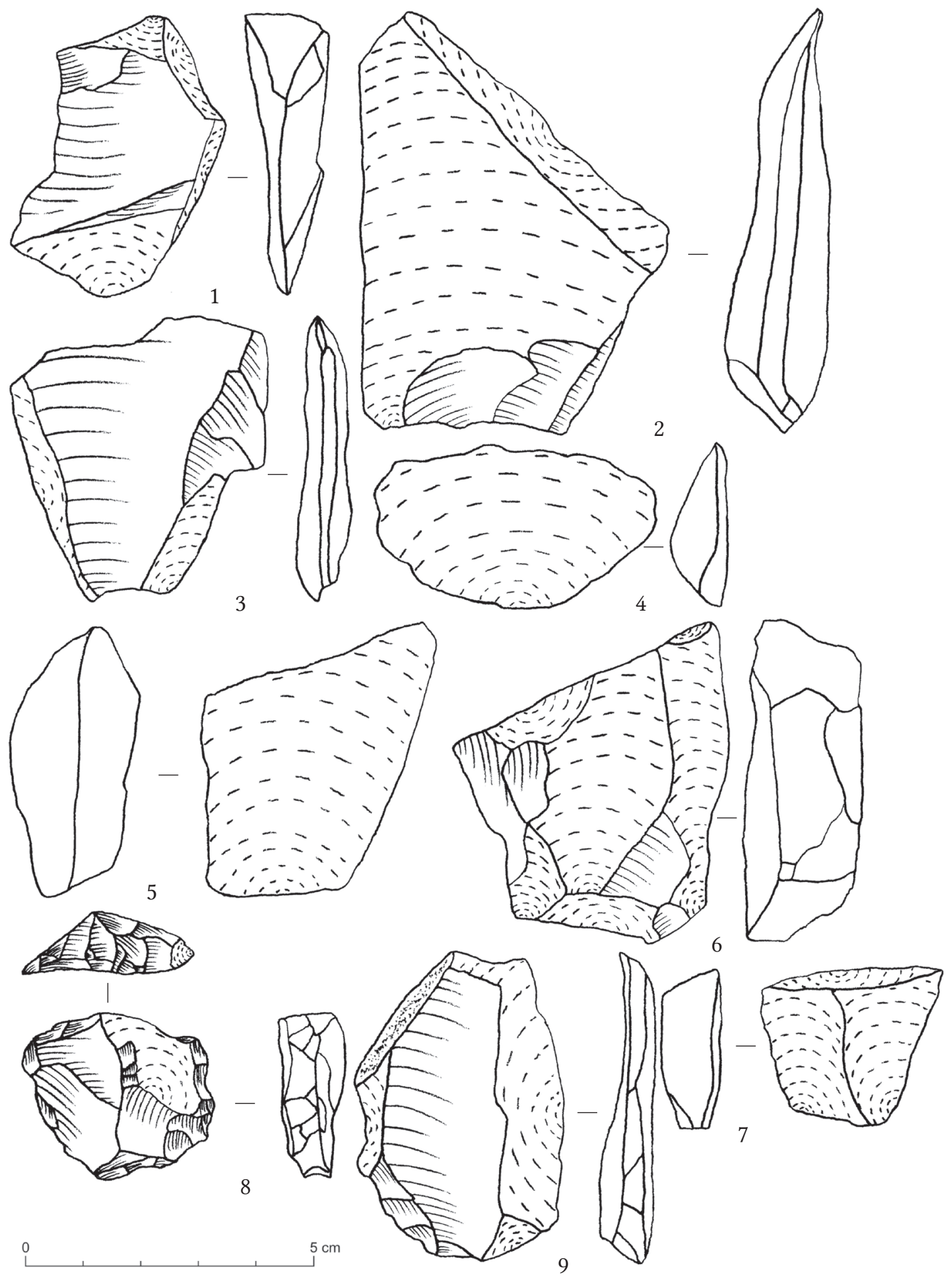

Fig. 12. Stone artifacts from 2/2018 sondage in Stará Lubovňa - Lesopark site: 1 - over-passed blade, 2-7, 9 - flakes, 8 - end-scraper. Raw materials: 1-5, 7-9 - red radiolarite, 6 - green radiolarite.

resemble forms associated with the initial phase of raw material processing. ${ }^{9}$ They can be compared to flake and blade blanks (Fig. 9.1,4,11,12), which seems to be knapped from prepared cores.$^{10}$ Certainly, semi-products of prepared character were also found in the $2 / 2018$ sondage (Fig. 11.6,10). Furthermore, two cores were found in $1 / 2018$ sondage, admittedly in an initial

9 e.g. Ginter 1974, 119. Pl. XXXIV; Sobczyk 1993, Pl. XIII; Pl. XIV.

10 see e.g. Rakoca - RozbiEgalski 2015, 416. 
form (Fig. 9.5), but the second sondage did not reveal any cores, only a pre-core (Fig. 11.9), which also can be significant. The other categories of findings are occasionally represented. It is also worth to mention the large amounts of natural fragments or blocks in the $2 / 2018$ sondage (see above). This kind of accumulation suggests that the place was used for pre-processing of extracted raw materials, especially near mining areas. ${ }^{11}$

\section{Tools}

Tools were distinguished in both $1 / 2018$ and 2/2018 sondages. This kind of items were much more numerous in the area of $1 / 2018$ sondage (Fig. 8 ).

The sondage 1/2018 revealed, among others, fragments of retouched blades or flakes (Fig. 9.2,15,16; Fig. 10.3,4), perforators (Fig. 9.3,9,10), a knife and end-scraper combined (Fig. 9.7), burins (Fig. 9.8; Fig. 10.2,5), knife-like artifact (Fig. 9.13), end-scrapers (Fig. 9.14; Fig. 10.6), retouched natural fragment (Fig. 10.1), mining tools (Fig. 10.7,8) and two products of the mining tool forms, in the form of a hoe (Fig. 10.7,8). The following were found in 2/2018 sondage: burin (Fig. 11.1), fragment of retouched blade and retouched flakes (Fig. 11.3,4,11) and an end-scraper (Fig. 12.8). Retouched blades or flakes are common, non-specific forms, typical for communities that used stones as a raw material for tools. ${ }^{12}$

The presence of tools made from natural fragments is also significant (Fig. 9.13; Fig 10.1). This is characteristic of places located near sources of raw material, that could be easily available and where no attention was given to its long transport. ${ }^{13}$ This may therefore certify that the site is rich in radiolarite.

However, despite a relatively small series of tools, in the form of end-scrapers, burins and perforators, it is possible to suggest dating within a single period and one taxonomic unit, which is possible due to typological analysis. ${ }^{14}$

Tab. 1. Composition of the archaeological material of Stará Lubovňa - Lesopark site

\begin{tabular}{|l|c|c|}
\hline \multicolumn{1}{|c|}{ Type of artefact } & 1/2018 sondage & $2 / 2018$ sondage \\
\hline pre-cores & 0 & 1 \\
\hline cores & 2 & 0 \\
\hline technical forms & 1 & 1 \\
\hline blades & 2 & 5 \\
\hline short accidental blades & 1 & 0 \\
\hline fragments of removal & 2 & 1 \\
\hline flakes & 22 & 22 \\
\hline tools & 20 & 6 \\
\hline chunks with negatives & 44 & 16 \\
\hline Total & 96 & 52 \\
\hline
\end{tabular}

11 Ginter 1974, 13; LeCH - Werra 2013.

12 e.g. Dobrzyński - Piątkowska 2012, 57; Bobak - Połtowicz-Bobak 2009, 138.

13 see e.g. BArgiet - Libera 1996, 37; Ginter 1974, 36; Trela-Kieferling 2017, 51.

14 GinTER - KozŁowski 1990. 


\section{Chronological and cultural classification}

It seems that the presented finds belong to a single period - Late Palaeolithic. The closest analogies for high massive end-scraper (Fig. 9.14), amorphous form of the same kind of tool (Fig. 10.6), and also short flake form (Fig. 12.8) can be found in the Magdalenian sites. ${ }^{15}$ Burins of medial truncation form (Fig. 9.8), back truncation form (Fig. 10.2) and backed dihedral burin (Fig. 10.5) also show connections with the concerned cultural unit. ${ }^{16}$ The same note also applies to perforators (Fig. 9.3,9,10). ${ }^{17}$ Also the above mentioned core, found in this site (Fig. 2.2), may belong to that culture..$^{18}$ At the same time, it should be concluded that these forms do not appear to be analogous to the Epigravettian inventories, although certain connections with this cultural unit cannot be excluded. ${ }^{19}$

It should be noted that a certain settlement type related to the Epigravettian culture occurred along the Poprad river, although on a small scale. ${ }^{20}$ However, the Magdalenian culture is more strongly represented in this area. ${ }^{21}$ Thus, it should be concluded that at the moment the presented material most likely can be associated with Magdalenian culture.

\section{The question of raw material exploitation}

Extremely important finds are two tools made of in the form of a hoe (see above). Therefore, it can be presumed that Stará Lubovňa - Lesopark site was used to search and extract raw material by Late Palaeolithic community.

As for the artefacts themselves, analogies can be found in the Palaeolithic sites, ${ }^{22}$ including those dated to the Late Palaeolithic. ${ }^{23}$ However, it seems that the artefacts are universal. Their form was adapted to the function of digging up and the modification was simple and temporary. Such tools are also known from Neolithic sites, for example an artefact discovered in Beskid Niski Range, ${ }^{24}$ or also from mining places rich in flint clusters, where the prepared tools were used for mining purposes. ${ }^{25}$ Similar forms of mining tool can also be found at sites dating back to the Bronze Age. ${ }^{26}$

Versatility of such artifacts can also be seen in the spread of this kind of materials. Examples from European sites were highlighted previously in the article, whereas examples of similar

15 Ginter et al. 2002, 123. Ryc. 12.1,2; JastrzęBSki - Libera 1987, 16. Ryc. 6.2,11; Połtowicz-Bobak et al. 2014 , 243. Ryc. 5.7,10; Soвсzyк 1993, Pl. XXIII.7; Wiśniewski 2015, 137. Pl. 23.12,18.

16 Ginter 1974, Pl. XXIII.1,3; JastrzębSki - Libera 1987, 18. Ryc. 8.3; Valde-Nowak et al. 2007, 17. Pl. V.5; WIŚNIEWSKI 2015, 153. Pl. 39.9,10.

17 Jastrzębski - Libera 1987, 33. Ryc. 20.12; Połtowicz-Bobak et al. 2014, 242. Ryc. 4.8; Przeździecki et al. 2012, Fig. 8.15,17,22; WiśnIEWSKi 2015, 139. Pl. 25.25,28.

18 Alexandrowicz 1992, 73. Pl. III.1; BobaK et al. 2010, 71. Ryc. 8.2.

19 comp. BÁnesz et al. 1992; Wilczyński 2006; VAlde-NowaK 2008; KAminsKá - Nemergut 2014.

20 VALDE-NowaK et al. 2007, 9.

21 e.g. Drobniewicz et al. 1997; VAlde-Nowak et al. 2007, 9-10; WAWrzcZAK - Profus 2012, 123, 125; Biernat et al. 2013, 5-7; Wawrzczak - Profus 2016, 188; VAlde-Nowak et al. 2018; Wawrzczak 2018, 120; WawRZCZAK 2020, 128.

22 Šatavičıus 2012, 78. Fig. 13.

23 e.g. Boschian 1995, 38. Fig. 4.

24 Budziszewski - SKowronek 2001, 153. Fig. 9.B.

25 e.g. Borkowski - Migal 1988, 86; Migal - SAŁACiński 1997, 106. Fig. 8.

26 see BArgiet - Libera 1996, 46. Ryc. 6.a. 
products could be seen also on the African territory. ${ }^{27}$ It is therefore possible to establish the universality of mining forms for communities extracting stone raw material, regarding both - territory and chronology. In this case, the $1 / 2018$ sondage determines dating and cultural affiliation of artefacts with Late Palaeolithic materials and probably with Magdalenian culture.

The potential site of extraction should also be indicated. The $2 / 2018$ sondage indicates materials from pre-treatment of raw material (see above). At the same time, in the forest area, where the excavation is located, traces of small ground hollows can be observed. It may be remnants of exploration and mining activities of the Late Palaeolithic societies. Wołowice mining site of Magdalenian culture can be given as a clear example, where pre-processing of artefacts and mining tools were found, whereas no typical living camp materials were present. ${ }^{28}$ The above-mentioned site also revealed mining shafts up to $2 \mathrm{~m}$ depth, where stone materials of production were found.$^{29}$ It is therefore possible that Stará Lubovňa - Lesopark site could be regarded as a site of mining character. If so, it would be the second prehistoric mine of stone raw materials within present-day territory of Slovakia. Previously, a mining site was discovered in the Biele Karpaty area, where also shafts were used to search for good quality of radiolarite raw material. ${ }^{30}$ Furthermore, there are known radiolarite outcrops in Slovakia (Vlara basin), where probably further mines exist. ${ }^{31}$ However, in both cases mentioned above, the artefacts were not dated as precisely as in Stará Lubovňa - Lesopark site. The artefacts found in Sromowce Wyżne (Pieniny) could confirm the possibility of extracting radiolarite from exposed areas, however, this site is dated to the beginning of the Bronze Age. ${ }^{32}$

Of course, it is possible that some of the observed extractions may be dated to later epochs. It seems probable, as raw material used for the manufacture of gunflints, was extracted from these sites in the Modern period..$^{33}$ Limnosilicites material were used for production of tiles, necessary for stoves. ${ }^{34}$ This raise the possibility of some "destruction" of the Late Palaeolithic site by later modern activities.

\section{Conclusion}

In 2018, a new archaeological site Stará L'ubovňa - Lesopark was discovered. It is located in the area north to the town. Small archaeological excavations were carried out in the form of two sondages (1/2018 and 2/2018) in the same year. As a result of this work, artefacts made of local radiolarite were discovered.

Chronologically, the site should be assigned to the Late Palaeolithic. Although it is difficult to affiliate it to an appropriate unit, Magdalenian culture is suggested.

It seems, based on the findings, that this place can be considered as a mine and an occupation located in its close vicinity. This is confirm by different nature of two areas (1/2018 and 2/2018 sondages). The mine was used to extract raw material from exposed surface using the discov-

27 e.g. Christiana KöHler et al. 2017, Fig. 10.

28 see Dagnan-Ginter 1973; KozŁowski - KozŁowski 1977, 165.

29 Dagnan-Ginter 1974; KozŁowski - KozŁowski 1977, 165.

30 see Cheben - Cheben 2014 for further literature; CHeben et al. 2018.

31 Cheben et al. 1995.

32 WAwrZCZAK 2018, 126.

33 e.g. SimÁn 1995, 382.

34 CheBen - IllášovÁ 2002, 111. 
ered tools (Fig. 10.7,8). Afterwards, it was pre-treated in the nearby area (2/2018 sondage), and used for making blanks and tools (1/2018 sondage).

The archaeological site Stará L'ubovňa - Lesopark appears to be incredibly interesting and opens new perspective to learn about the activities of the Late Palaeolithic societies in the Carpathian area.

\section{References}

Alexandrowicz, S. W. - Drobniewicz, B. - Ginter, B. - KozŁowski, J. K. - Madeyska, T. - NadaChowski, A. - Pawlikowski, M. - Sobczyк, K. - Szyndlar, Z. - Wolsan, M. 1992: Excavations in the Zawalona Cave at Mników (Cracow Upland, Southern Poland). Folia Quaternaria 63, 43-77.

Bańdo, Cz. - Dagnan-Ginter, A. - Holen, S. - KozŁowski, J. K. - Montet-White, A. - PawlikowSKI, M. - SовсZYк, K. 1992: Wołowice, province of Kraków (flint extraction and processing site). Recherches Archéologiques de 1990, 5-25.

BArgiet, B. - LiberA, J. 1996: Wyniki badań pracowni nakopalnianej w Nowym Rachowie. Archeologia Polski Środkowowschodniej 1, 35-48.

BÁnesz, L. - Hromada, J. - Desbrosse, R. - Margerand, I. - KozŁowski, J. K. - Sobczyk, K. - PawliKowski, M. 1992: Le site de plein air du paléolithique supérieur de Kašov 1 en Slovaquie orientale (Etude préliminaire dune structure spatiale des outillages épigravettiens en obsidienne). Slovenská Archeológia 40, 5-28.

Biernat, M. - SojÁk, M. - VAlde-Nowak, P. 2013: The complex of archaeological sites on the Litmanovská hill in Jarabina (Northern Slovakia). Slovenská Archeológia 61, 1-20.

Bobak, D. - Łanczont, M. - Nowak, A. - Po£тowicz-BobaK, M. - ToкArczyк, S. 2010: Wierzawice, st. 31 - nowy ślad osadnictwa magdaleńskiego w Polsce południowo-wscodniej. Materiaty $i$ Sprawozdania Rzeszowskiego Ośrodka Archeologicznego 31, 63-78.

Bовак, D. - Poєтоwicz-Вовак, M. 2009: Przyczynek do rozpoznania osadnictwa paleolitycznego na terenach Płaskowyżu Głubczyckiego. Dwa nowe stanowiska powierzchniowe z Pilszcza. Śląskie Sprawozdania Archeologiczne 51, 131-140.

BorkowsKi, W. - MigAL, W. 1988: Badania wyrobisk szybu 7/610 w Krzemionkach w latach 1984-1986. Sprawozdania Archeologiczne 40, 63-94.

Boschian, G. 1995: The "San Bartolomeo" shelter: a flint exploitation site in Central Italy. Archaeologia Polona 33, 31-40.

Budziszewsкi, J. - Sкоwroneк, M. 2001: Results of the preliminary archaeological researches in the mount Cergowa massif, the Lower Beskid Mountains. Prace Komisji Prehistorii Karpat 2, 145-164.

Cheben, I. - Cheben, M. 2014: The exploration of a mining site for radiolarite in the White Carpathians area. In: Bostyn, F.-Giligny, F. (eds): Lithic raw material resources and procurement in preand protohistoric times. Proceedings of the 4th International Conference of the UISPP Commission on Flint Mining in Pre- and Protohistoric Times (Paris, 10-11 September 2012). Oxford, 87-92.

Cheben, I. - Cheben, M. - Nemergut, A. - SojÁk, M. 2018: The latest knowledge on use of primary sources of radiolarites in the central Váh region (the microregion of Nemšová-Červený Kameň). In: Werra, D. H.-Woźny, M. (eds): Between history and archaeology. Papers in honour of facek Lech. Oxford, 115-132. doi: 10.2307/j.ctvndv6qh.15

Cheben, I. - IllášovÁ, L. 2002: Chipped industry made of limnoquarzite from Žiarska Kotlina hollow. In: Cheben, I.-Kuzma, I. (eds): Otázki neolitu a eneolitu našich krajín - 2001. Zborník referátov $z$ 20. pracovného stretnutia bádatelov pre výskum neolitu a eneolitu Čiech, Moravy a Slovenska Liptovská Sielnica 9.-12. 10. 2001. Nitra, 105-112. 
Cheben, I. - Illášová, L. - Hromada, J. - OžvoldovÁ, L. - Pavelčík, J. 1995: Eine Oberflächengrube zur Förderung von Radiolarit in Bolešov. Slovenská Archeológia 43, 185-204.

Christiana Köhler, E. - Hart, E. - Klaunzer M. 2017: Wadi el-Sheikh: A new archaeological investigation of ancient Egyptian chert mines. PLoS ONE 12, e0170840. doi: 10.1371/journal.pone. 0170840

Dagnan-Ginter, A. 1973: Le problème des atelier de la taille de silex en Paléolithique superieur de coté nord des Karpates. Acta Archaeologica Carpathica 14, 75-80.

Dagnan-Ginter, A. 1974: Wołowice (an Upper Palaeolithic workshop site). Recherches Archéologiques, $7-16$.

Dobrzyński, M. - PiąTKowska, K. 2012: Zagadnienie eksploatacji łuszczniowej w kulturze pucharów lejkowatych na podstawie stanowiska 8/19 w Piaskach Wielkich, pow. Świdnik, woj. lubelskie. Materiaty i Sprawozdania Rzeszowskiego Ośrodka Archeologicznego 33, 43-61.

Drobniewicz, B. - Doktor, M. - Sobczyk, K. 1997: Petrographical composition and provenance of siliceous artefacts on the archaeological sites in the region of Spisz and Pieniny Mountains (southern Poland). In: Schild, R.-Sulgostowska, Z. (eds): Man and flint-Proceedings of the VIIth International Flint Symposium Warszawa - Ostrowiec Swiętokrzyski, September 1995. Warszawa, 195-200.

GinTER, B. 1974: Wydobywanie, przetwórstwo i dystrybucja surowców i wyrobów krzemiennych w schyłkowym paleolicie północnej części Europy Środkowej. Przegląd Archeologiczny 22, 5-122.

Ginter, B. - KozŁowski, J. K. 1990: Technika obróbki i typologia wyrobów kamiennych paleolitu, mezolitu i neolitu. Warszawa.

Ginter, B. - Połtowicz, M. - Pawlikowski, M. - Skiba, S. - Trąbska, J. - Wacnik, A. - WiniarskaKABACiŃSKa, M. - Wojtal, P. 2002: Dzierżysław 35 - stanowisko magdaleńskie na przedpolu Bramy Morawskiej. In: GANCARSKI, J. (ed.): Starsza i środkowa epoka kamienia $w$ Karpatach polskich. Krosno, 111-145.

JASTRZ̨̨BSKI, S. - Libera, J. 1987: Stanowisko późnomagdaleńskie w Klementowicach-Kolonii w świetle badań 1981-1982 r. Sprawozdania Archeologiczne 39, 9-52.

KaminskÁ, L. - Nemergut, A. 2014: The Epigravettian chipped stone industry from the Nitra III site (Slovakia). In: Biró, K. T.-MArkó, A.-P. BAjnok, K. (eds): Aeolian scripts. New ideas on the lithic World. Studies in honour of Viola T. Dobosi. Budapest, 93-119.

KasenčÁkovÁ, Z. - WawrzczaK, M. 2018: Stará L’ubovňa - Lesopark, okr. Stará L’ubovňa. Nálezová správa $z$ archeologického výskumu „,na ploche náhodne objaveného náleziska, parc. ̌́. KN-C 4476 a KN-C 4357/6 k. u. Stará L’ubovňa. Manuscript in the Museum in Stará L’ubovňa. Stará Lubovňa.

KučEROvÁ, M. - KASENČÁKovÁ, Z. - WAWRZCZAK, M. 2020: Svedectvá najstaršej minulosti. In: LAINCZ, E. MARcinová F. (eds): Libenow, Liblaw, Lubowla, Alt Lublau, Ólubló... Stará L’ubovña (monografia mesta). Stará L’ubovňa, 82-115.

KozŁowski, J. K. - KozŁowski, S. K. 1977: Epoka kamienia na ziemiach polskich. Warszawa.

KunÁKovÁ, L. - ŠTeFKo, R. - BAČík, R. 2016: Evolution of the landscape potential for recreation and tourism on the example of microregion Minčol (Slovakia). E-review of Tourism Research 2, 335-354.

LeCh, J. - Werra, D. 2013: Artefakty w przestrzeni prehistorycznych pól górniczych. In: Czyżewski, Ł. A. (ed.): Artefakt w przestrzeni. Krzemienica - skupienie - stanowisko - region. 10. Warsztaty Krzemieniarskie SKAM, 23 - 25 października 2013, Toruń. Toruń, 23-28.

LiBERA, J. 2019: Materiały ze skał krzemionkowych odkryte na stanowisku $1 \mathrm{w}$ Dubecznie (Pojezierze Łęczyńsko-Włodawskie). In: TARAs, H. (ed.): Dubeczno, stanowisko 1 (Pojezierze Łęczyńsko-Wtodawskie). Materiaty $z$ badań archeologicznych $w$ latach 1986-1987. Lublin, 197-245.

Migal, W. - SaŁaciński, S. 1997: Studies at Krzemionki during the last decade. In: Schild, R.-Sulgosтоwsкa, Z (eds): Man and flint - Proceedings of the VIIth International Flint Symposium Warszawa - Ostrowiec Świętokrzyski, September 1995. Warszawa, 103-108. 
NЕмс̌ок, J. 1990: Vonkajšie flyšové pásmo. In: NЕмс̌ок, J. (ed.): Vysvetlivky ku geologickej mape Pienín, Črgova, Lubovnianskej a Ondavskej Vrchoviny 1 : 50000. Bratislava, 51-73.

Poєtowicz-Bовак, M. - Вовак D. - Gęвica P. 2014: Nowy ślad osadnictwa magdaleńskiego w Polsce południowo-wschodniej. Stanowisko Łąka 11-16 w powiecie rzeszowskim. Materiaty i Sprawozdania Rzeszowskiego Ośrodka Archeologicznego 35, 237-248. doi: 10.15584/misroa.2015.36.2

Przeździecki, M. - Migal, W. - Krajcarz, M. - Pyżewicz, K. 2012: Obozowisko kultury magdaleńskiej na stanowisku 95 „Mały Gawroniec” w Ćmielowie, pow. ostrowiecki, woj. świętokrzyskie (Pl. 104-115). Światowit 7(48)B, 225-234.

RAKoca, A. - RozBIEgalski, P. 2015: Charakterystyka nakopalnianej pracowni krzemieniarskiej z okresu schyłkowego paleolitu na podstawie materiałów krzemiennych ze stanowiska Kłodawa 3, pow. Gorzowski, woj. Lubuskie. Folia Praehistorica Posnaniensia 20, 397-427. doi: 10.14746/2015.20.22

SimÁn, K. 1995: H1 Miskolc-Avas Hill. Prehistoric mine on the Avas hill at Miskolc. Archaeologia Polona 33, 371-382.

Sовсzук, K. 1993: The Late Palaeolithic flint workshops at Brzoskwinia-Krzemionki near Kraków. Kraków.

ŠATAVIČıUs, E. 2012: Titnago kasimo ir apdirbimo dirbtuvès prie Titno ežero. Archaeologia Lituana 13, 66-83. doi: 10.15388/ArchLit.2012.0.1190

Trela-Kieferling, E. 2017: Narzędzia „podomowe” z pracowni / kopalni krzemieniarskiej w Bęble stan. 4, gm. Wielka Wieś. Acta Archaeologica Lodziensia 63, 49-57.

VALDe-NowaK, P. 2008: Paleolityczne zabytki ze stanowiska Marhaň, okr. Bardejov (Słowacja). In: Machniк, J. (ed.): Archeologia i środowisko naturalne Beskidu Niskiego w Karpatach. Część II. Kurimská Brázda. Kraków, 139-156.

Valde-Nowak, P. - Kraszewska, A. - Cieśla, M. - Nadachowski, A. 2018: Late Magdalenian campsite in a rock shelter at the Obłazowa Rock. In: VALDE-NowAK, P.-SobczyK, K.-NowAK, M.ŹrąKa, J. (eds): Multas per Gentes et Multa per Saecula. Amici Magistro et Collegae suo Ioanni Christopho Koztowski Dedicant. Kraków, 175-183.

VALDE-NowaK, P. - SojÁk, M. - WĄS, M. 2007: On the problems of the Late Palaeolithic settlement in northern Slovakia. Example of Stará L'ubovňa site. Slovenská Archeológia 55, 1-22.

WawrzczaK, M. 2018: Archeologiczne badania powierzchniowe w Pieninach. III. komunikat z prac w 2013 roku. Pieniny - Przyroda i Człowiek 15, 117-129.

Wawrzczak, M. 2020: Archeologiczne badania powierzchniowe w Pieninach. IV komunikat z prac wykonanych w 2014 roku. In: Bodziarczyк, J. (ed.): Pieniny - Przyroda i Człowiek. Monografie, 16. Kraków, 123-135.

Wawrzczak, M. - Profus, T. 2012: Archeologiczne badania powierzchniowe w Pieninach. I. Historia badań i założenia metodyczne. Pieniny - Przyroda i Człowiek 12, 117-127.

Wawrzczak, M. - Profus, T. 2016: Archeologiczne badania powierzchniowe w Pieninach. II. komunikat z prac w 2012 roku. Pieniny - Przyroda i Człowiek 14, 185-192.

Wilczyński, J. 2006: The Upper Paleolithic workshop at the site Piekary IIA sector XXII leyer 5. Sprawozdania Archeologiczne 58, 175-203.

Wiśniewski, T. 2015: Magdalenian settlement in Klementowice. In: WiśNIEWsKI, T. (ed.): Klementowice. A Magdalenian site in eastern Poland. Lublin, 15-179. 